\title{
Online Additional Material: Can Compulsory Military Service Raise Civilian Wages? Evidence from the Peacetime Draft in Portugal
}

\author{
David Card and Ana Rute Cardoso
}

February 9, 2012

TABle A.1: Types of LeAVE AND Their CODING DURING The PERIOD Under ANALYSIS

\begin{tabular}{|c|c|c|c|c|c|}
\hline \multirow{2}{*}{$\begin{array}{l}\text { Type of } \\
\text { Leave }\end{array}$} & \multirow{2}{*}{$\begin{array}{c}\text { Worker } \\
\text { Reported (1) }\end{array}$} & \multicolumn{2}{|c|}{ QP Coding of } & \multirow{2}{*}{$\begin{array}{l}\text { Coding of } \\
\text { "on Leave" }\end{array}$} & \multirow[t]{2}{*}{ Notes } \\
\hline & & Wage & Hours & & \\
\hline Sickness & yes & $\begin{array}{l}\text { missing, } \\
\text { if leave } \\
\text { longer } \\
\text { than } 3 \\
\text { days }\end{array}$ & $\begin{array}{l}\text { missing, } \\
\text { if leave } \\
\text { longer } \\
\text { than } 3 \\
\text { days }\end{array}$ & $=1$ & $\begin{array}{l}\text { Wage paid (approx. } 65 \% \text { of normal } \\
\text { wage) by the social security, after } 3 \text { days } \\
\text { of sickness. Estimated overall rate of } \\
\text { sickness absenteeism in Portugal: } 8 \% \\
\text { (EFILWC, 1997, p. 18). }\end{array}$ \\
\hline Maternity & yes & missing & missing & $=1$ & $\begin{array}{l}\text { Maternity leave started in Portugal in } \\
1976 \text {, when it lasted for } 90 \text { days. Cur- } \\
\text { rently, it lasts for } 120 \text { days. }\end{array}$ \\
\hline Strike & yes & missing & missing & $=1$ & $\begin{array}{l}\text { Average of } 0.016 \% \text { work days lost per } \\
\text { year during } 1986-1996 \text { (own computa- } \\
\text { tions based on Portugal, INE (1986- } \\
1996 \text { ) and Pordata (1986-1996)). }\end{array}$ \\
\hline Holiday & yes & reported & reported & $=0$ & \\
\hline Military & yes & missing & missing & $=1$ & \\
\hline
\end{tabular}

Note: (1) Instructions to fill out the questionnaire during the 1980s and 1990s stated that everyone engaged in the firm during the reference period should be listed, including: "the owner of the firm, if performing a function in the firm; unpaid and paid family members, if working in the firm more than one third of the normal duration of work; piece-rate workers; workers on short-term leave and those doing their military service" (Portugal, MT, Decree-Law 380/80, instructions on filling out column 2 of the Quadros de Pessoal form) [own translation]. Elsewhere in the instructions form, examples of short term leave are provided: sickness, maternity, holiday, strike. 


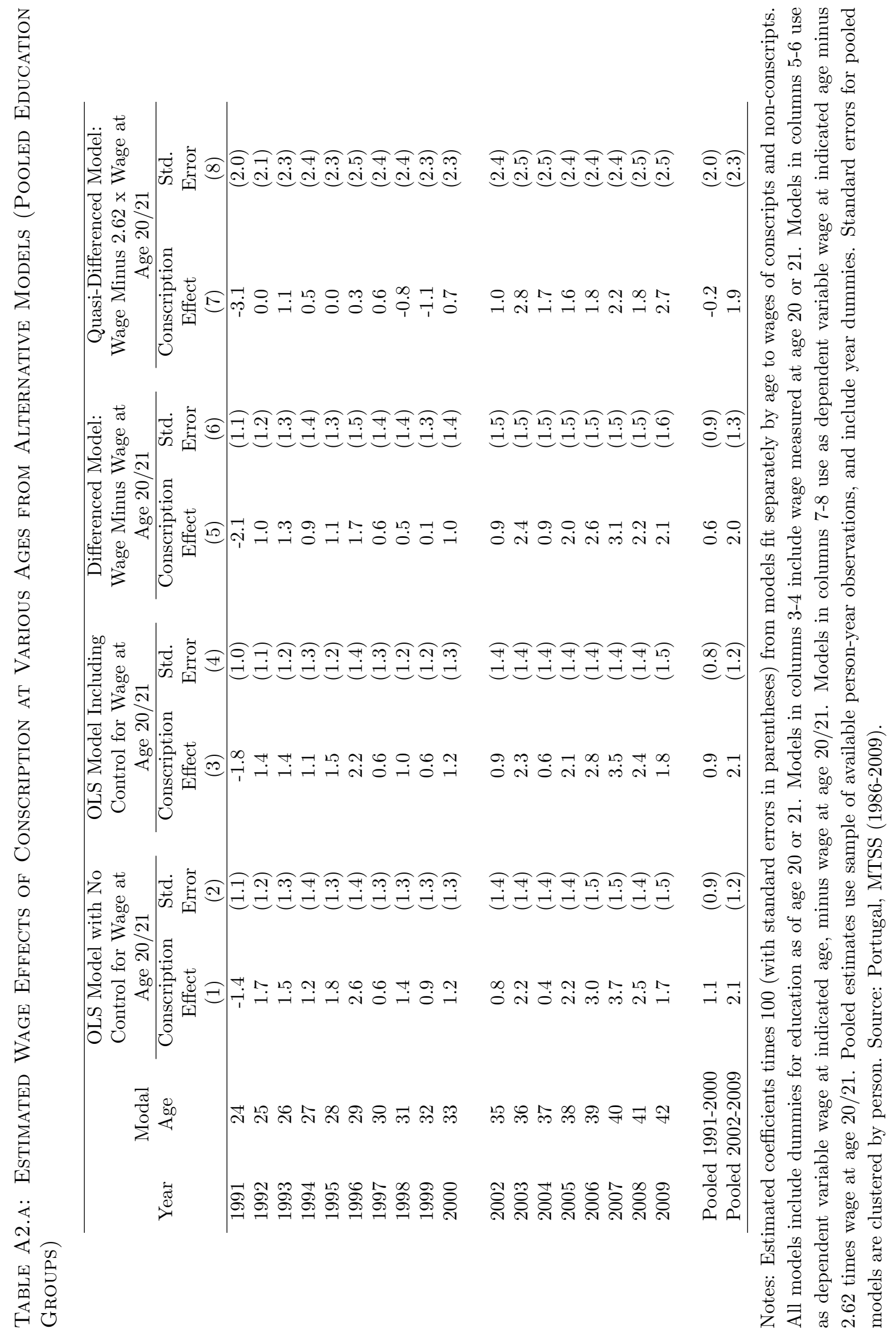




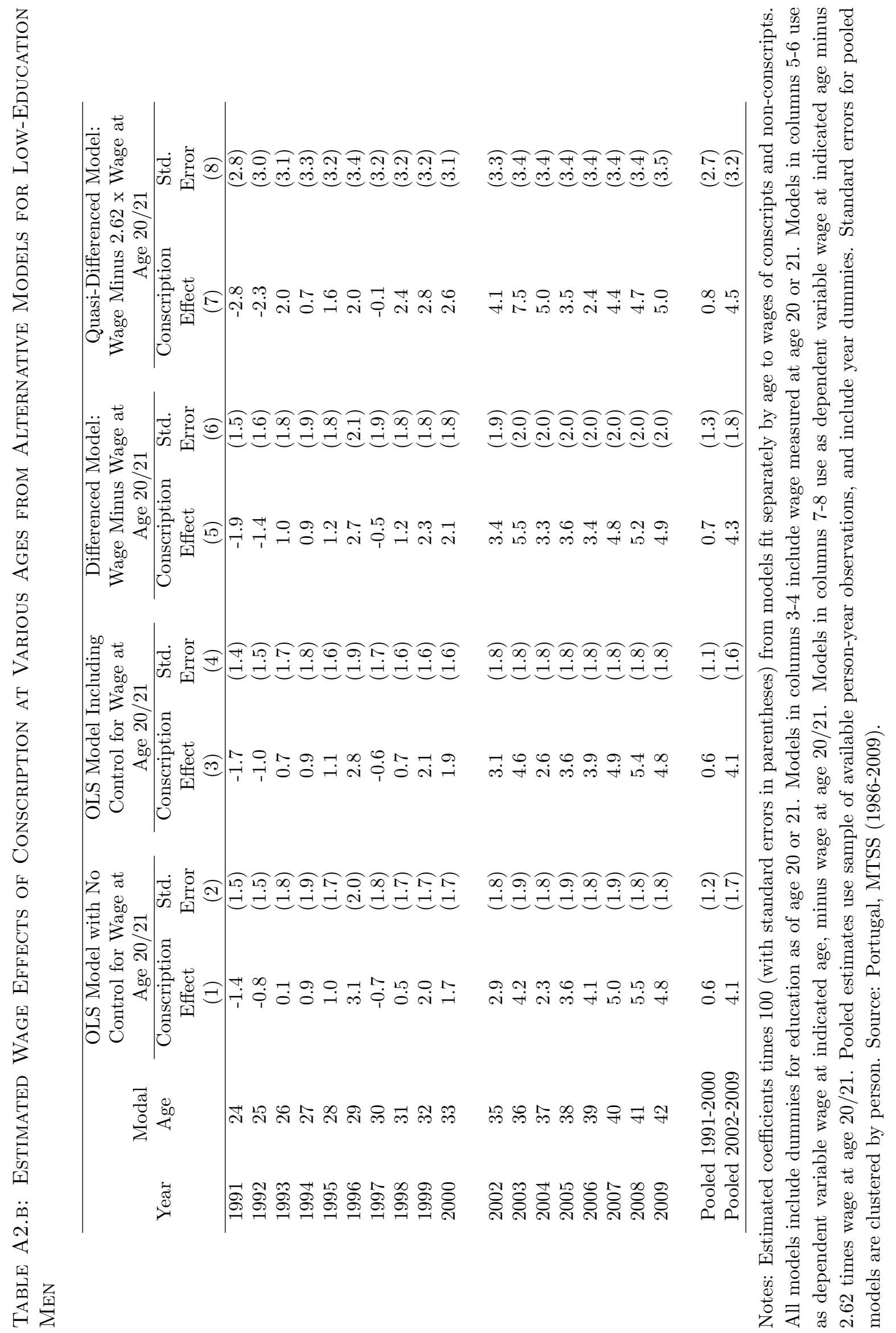




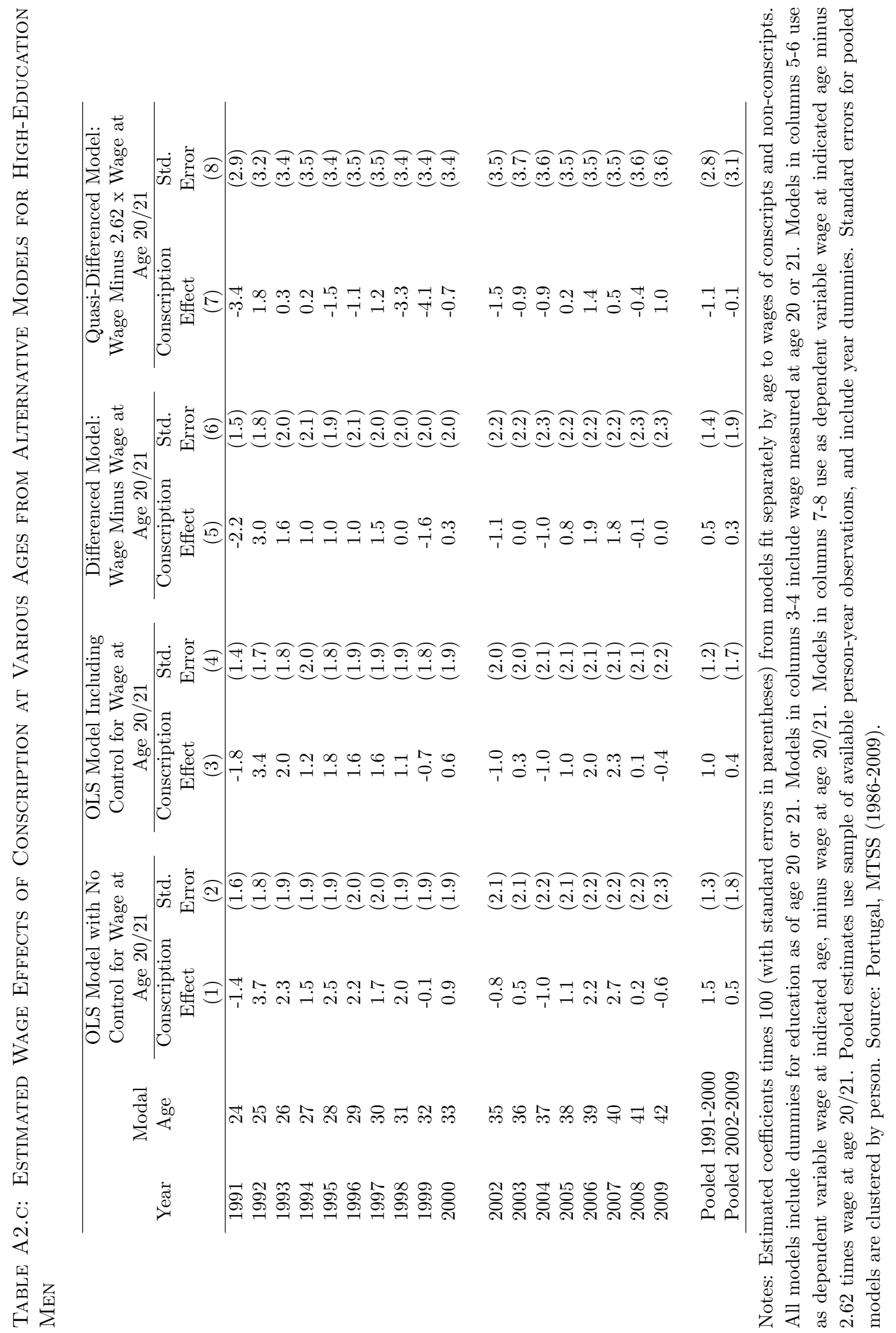




\section{Figure A.1: Age Profiles of Hourly Wages, Cohort 1967, Females}

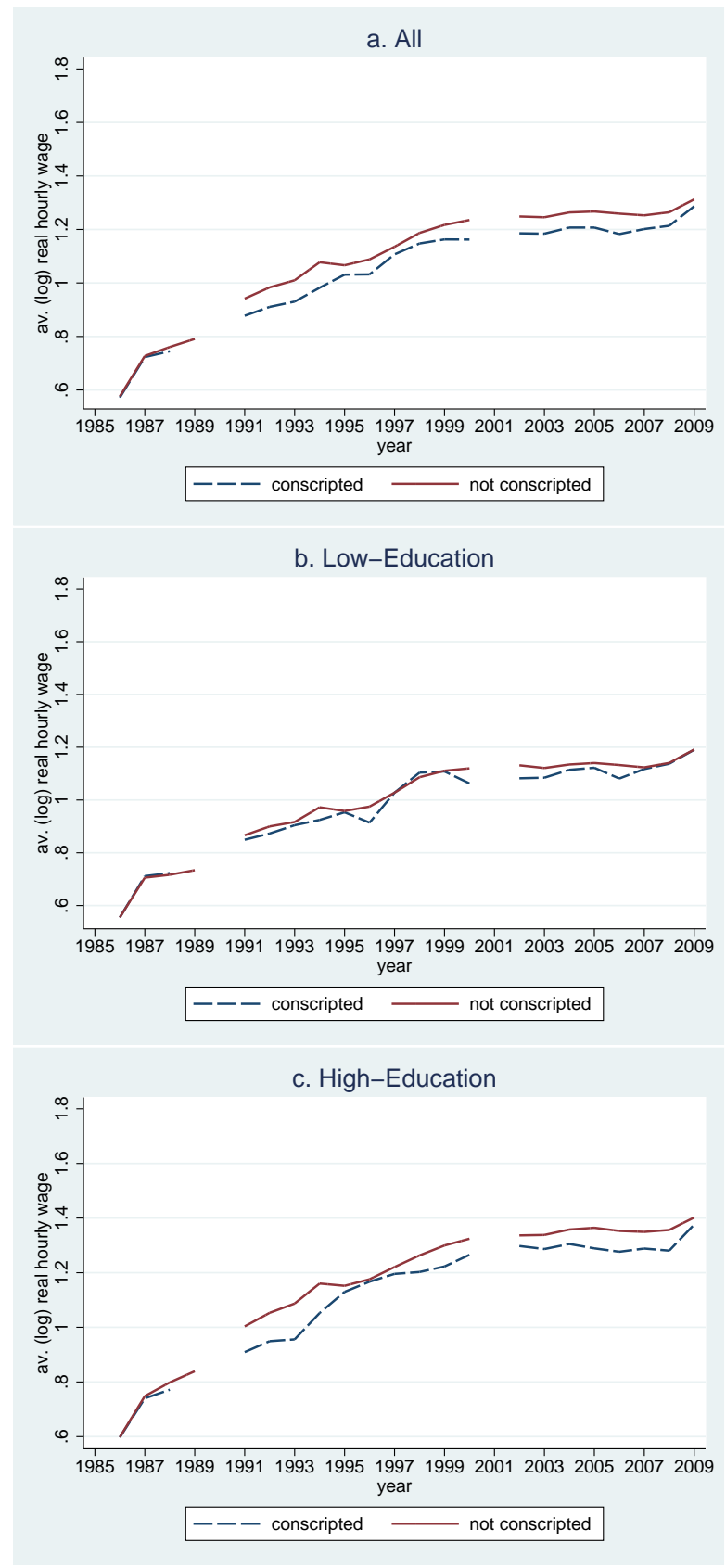

Note: 'Conscripted' is an individual working full-time in 1987 or 1988 and reported on leave during the years military enlistment is due; 'non-conscripted' is an individual observed working full-time during the years military enlistment is due. For the cohort born 1967, military enlistment was due the year the individual turned 21 and it lasted for 24 months. Source: Computations based on Portugal, MTSS (1986-2009). 


\section{Figure A.2: Age Profiles of Employment, Cohort 1967, Females}

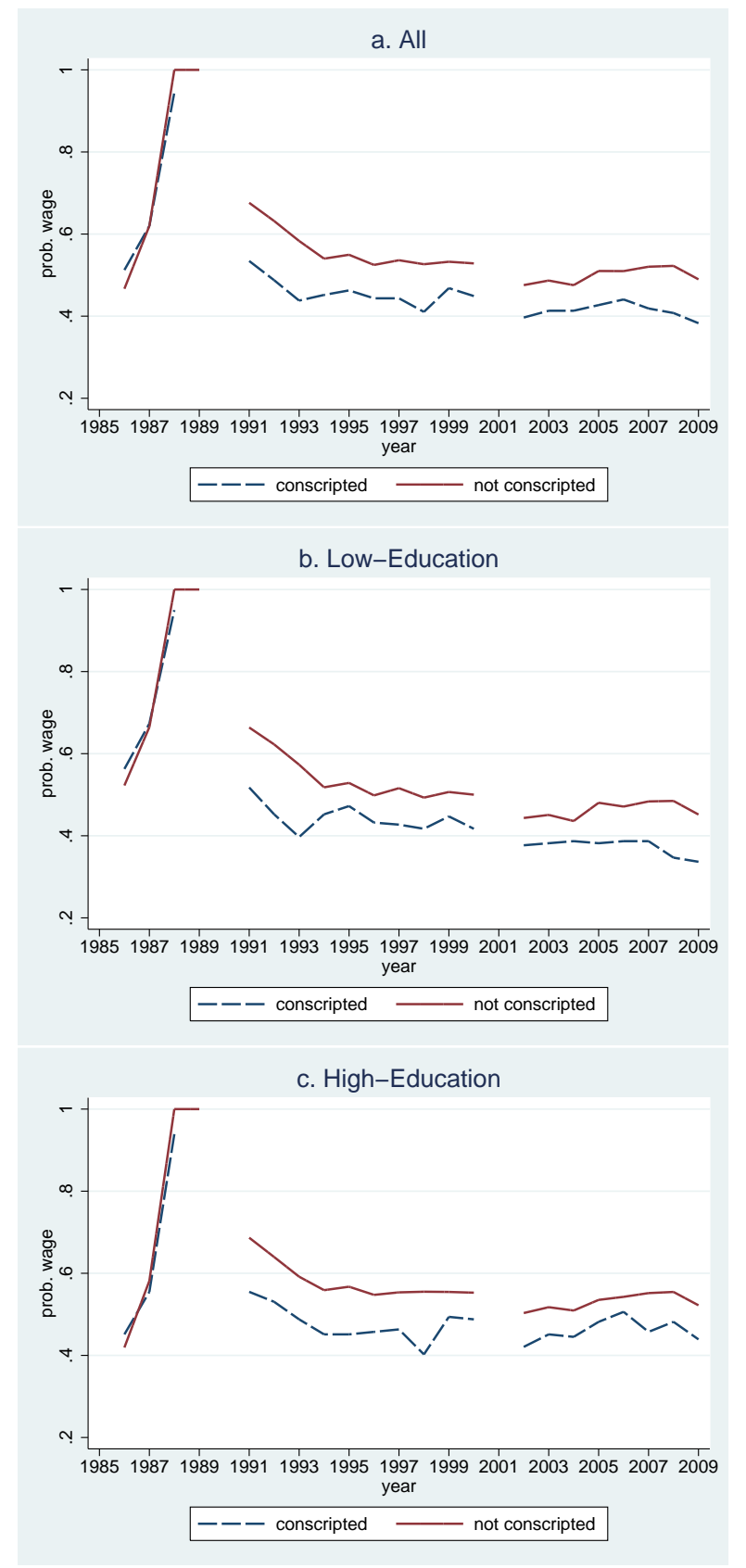

Note: 'Conscripted' is an individual working full-time in 1987 or 1988 and reported on leave during the years military enlistment is due; 'non-conscripted' is an individual observed working full-time during the years military enlistment is due. For the cohort born 1967, military enlistment was due the year the individual turned 21 and it lasted for 24 months. Source: Computations based on Portugal, MTSS (1986-2009). 
Figure A.3: Age Profiles of Hourly Wages, Cohort 1967, Males Early LABOr Market Entrants

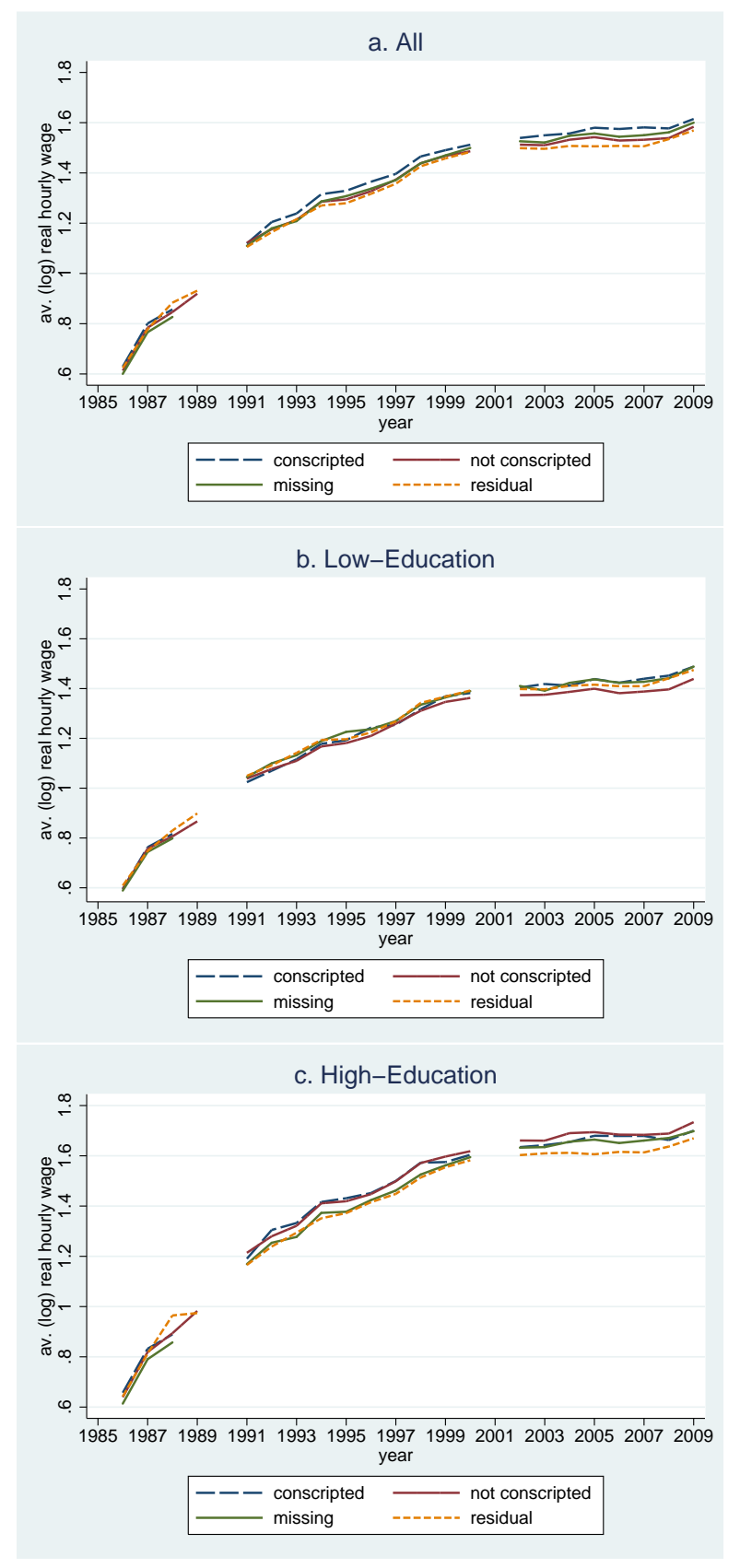

Note: Conscripted men include men who were working full time in 1987, and were on leave of absence (listed on the roster of employees with missing values for wages and hours) in 1988 and 1989, plus men who were working full time in 1988 and on leave in 1989. Non-conscripted men are those who were working full time in 1988 and 1989. Missing group in column 6 are those who were working full time in 1987 or 1988 and are not present in the QP in 1989. Residual group in column 7 are all men who were working full time in 1987 or 1988 and are not included as conscripts, non-conscripts, or missing. Source: Computations based on Portugal, MTSS (1986-2009). 
Figure A.4: Age Profiles of Employment, Cohort 1967, Males Early Labor MARKET ENTRANTS

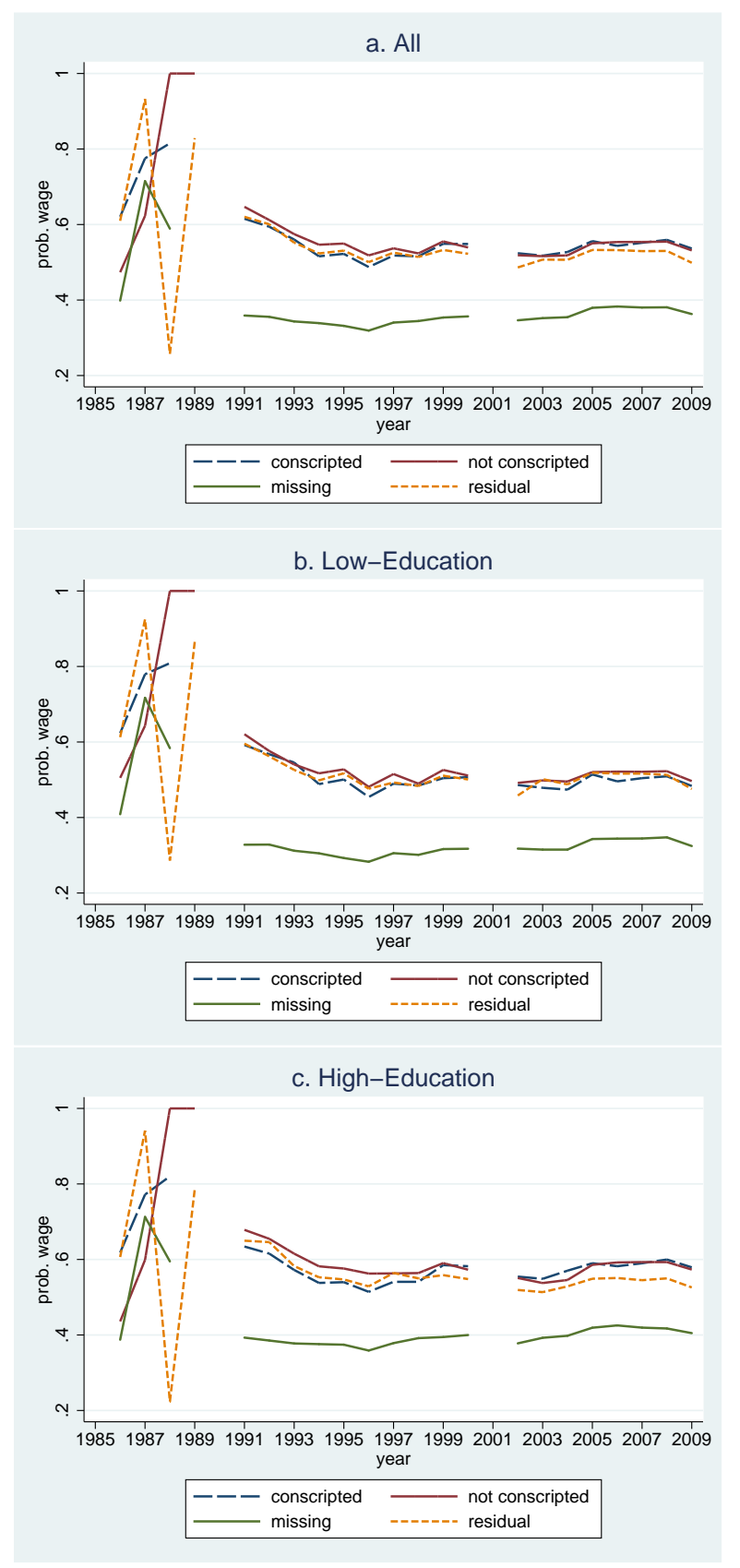

Note: Conscripted men include men who were working full time in 1987, and were on leave of absence (listed on the roster of employees with missing values for wages and hours) in 1988 and 1989, plus men who were working full time in 1988 and on leave in 1989. Non-conscripted men are those who were working full time in 1988 and 1989. Missing group in column 6 are those who were working full time in 1987 or 1988 and are not present in the QP in 1989. Residual group in column 7 are all men who were working full time in 1987 or 1988 and are not included as conscripts, non-conscripts, or missing. Source: Computations based on Portugal, MTSS (1986-2009). 


\section{References}

European Foundation for the Improvement of Living and Working Conditions. 1997. Preventing Absenteeism at the Workplace: Research Summary. Luxembourg: Office for Official Publications of the European Communities.

Pordata. 1986-1996. "Emprego." www.pordata.pt8 (accessed June 6, 2011).

Portugal. Instituto Nacional de Estatística. 1986-1996. "Greves." www.ine.pt (accessed July 6, 2011). 